\title{
IMPROVING THE COMPETENCY OF HIGH SCHOOL TEACHERS IN UNDERSTANDING AND DESIGNING QUESTIONS BASED ON MINIMUM COMPETENCY ASSESSMENT IN BABAT LAMONGAN DISTRICT
}

\author{
Siti Maghfirotul Ulyah*', Sediono ${ }^{2}$, Elly Ana ${ }^{3}$, Noviatus Sholihah ${ }^{4}$, Khoirun \\ Niswatin 5 \\ ${ }^{1,2,3}$ Department of Mathematics, Airlangga University, Surabaya \\ ${ }^{4,5}$ Statistics Study Program, Airlangga University, Surabaya \\ maghfirotul.ulyah@ fst.unair.ac.id*1, sediono101@ gmail.com ${ }^{2}$, elly- \\ a@fst.unair.ac.id ${ }^{3}$, noviatus.olihah-2018@fst.unair.ac.id ${ }^{4}$, khoirun.niswatin- \\ 2018@fst.unair.ac.id ${ }^{5}$ \\ *Corresponding Author
}

Received 05 November 2020; revised 28 May 2021; accepted 08 June 2021.

\begin{abstract}
ABSTRAK
Salah satu topik hangat dalam dunia pendidikan adalah dipaparkannya kebijakan mengenai penggantian Ujian Nasional (UN) menjadi Asesmen Kompetensi Minimum (AKM) dan survei karakter oleh Menteri Pendidikan dan Kebudayaan. Dengan adanya kebijakan baru tersebut, semua sekolah dan warga sekolah harus melakukan persiapan se-dini mungkin. Dikarenakan kebijakan ini belum pernah diterapkan sebelumnya, maka kebanyakan tenaga pendidik (guru) belum memiliki wawasan yang cukup mengenai AKM. Oleh karena itu, perlu dilakukan penelitian mengenai kompetensi guru dalam memahami dan merancang soal berbasis AKM. Para guru akan diberikan workshop yang bertujuan untuk memberikan wawasan dan kompetensi bagi guru untuk mempersiapkan diri menyongsong pelaksanaan AKM di masa mendatang dengan sasaran guru matematika dan IPA di tingkat sekolah menengah atas negeri di Kecamatan Babat (SMAN 1 Babat dan MAN 2 Lamongan). Workshop dan pendampingan bagi guru diberikan untuk mempersiapkan diri sebagai pionir pelaksanaan AKM yang memiliki kemampuan memahami dan merancang soal kategori numerasi. Para guru diberikan pre-test dan post-test pada saat workshop kemudian hasilnya akan dibandingkan dan dianalisis secara deskriptif dengan pendekatan kuantitatif. Hasil penelitian menyatakan bahwa dengan diberikannya workshop tersebut, terdapat peningkatan pada kemampuan guru dalam memahami soal berbasis AKM sebesar 24,19 poin. Namun, pada kemampuan merancang soal AKM hanya terdapat peningkatan sebesar 5,95 poin. Oleh karena itu, perlu dilakukan pembimbingan lanjutan pasca workshop.
\end{abstract}

Kata kunci: asesmen kompetensi minimum, numerasi, guru, matematika. 


\begin{abstract}
One of the latest topics in the world of education is the presentation of policies regarding the replacement of the National Examination (UN) into a Minimum Competency Assessment (AKM) and a character survey by the Minister of Education and Culture. With the new policy, all schools and school residents must make preparations as early as possible. Because this policy has never been implemented before, most educators (teachers) do not have sufficient insight into AKM. Therefore, it is necessary to conduct research on teacher competence in understanding and designing AKM-based questions. Teachers will be given a workshop that aims to provide insight and competence for teachers to prepare for the implementation of AKM in the future with the target of mathematics and science teachers at the state high school level in Babat District (SMAN 1 Babat and MAN 2 Lamongan). Workshops and mentoring for teachers are provided to prepare themselves as pioneers in the implementation of AKM who have the ability to understand and design numeracy category questions. The teachers were given pre-test and post-test during the workshop and the results would be compared and analyzed descriptively with a quantitative approach. The results of the study stated that by giving the workshop, there was an increase in the ability of teachers to understand AKM-based questions by 24.19 points. However, in the ability to design AKM questions, there was only an increase of 5.95 points. Therefore, it is necessary to carry out further post-workshop mentoring.
\end{abstract}

Keywords: minimum competency assessment, numeration, teacher, mathematics.

\title{
INTRODUCTION
}

The National Examination (NE) is a test for final graders at every level of primary and secondary education. This examination has caused controversy because of the huge amount of cheating, so it is no longer representative in measuring students' abilities. The national examination can affect students' psychological state, such as anxiety, fear, and decreased confidence. Most students lose confidence in doing examination questions because they are too afraid of not graduating and afraid of not being able to continue their education or career in the future (Bledsoe \& Baskin, 2014). In addition, the fear of not being able to reach the targetted score that has been determined can also be one of the feelings that can form a negative perception of the national examination (Solehah, 2012). According to a study by Hadi \& Arwan's (2011), a few weaknesses of national examination are: 1) educational disorientation in schools, 2) less meaningful learning process, 3) unfair ways of meeting standards, 4) only the 
cognitive sphere is measurable, 5) the lack of objectiveness in graduation determinant, 6) unfair measurement of learning outcomes, and 7) closing access to quality education for the poor.

Minister of Education and Culture, Nadiem Makarim, through Merdeka Belajar program decided that in 2021 NE will be changed to Minimum Competency Assessment (AKM) and character survey (Kemendikbud, 2019). This policy gains a lot of good responses. AKM is expected to be a more comprehensive assessment to measure students' minimum ability. Furthermore, AKM will contain material that includes literacy, numeration, and character education skill tests (Ndiung \& Jediut, 2020).

One of the motivations for initiating AKM was the results of PISA 2018. PISA stands for Programme for International Student Assessment held by the Organisation for Economic Cooperation and Development (OECD) since 2000. PISA measures the ability of 15 year olds to use their reading, mathematics, and science knowledge and skills to meet real-life challenges (OECD, 2020).

Indonesia is one of the countries participating in the implementation of PISA. The results of the PISA 2018 assessment concluded that Indonesia was ranked lower compared to other participating countries. In the reading category, Indonesia is ranked 72 out of 78 with $70 \%$ of students under minimum competency grades. Then in the mathematics category, the ranking is 72 out of 78 with $71 \%$ of students having grades below the minimum competency. In the science category it also still ranks low (70 out of 78 ) with $60 \%$ of students with grades under minimum competencies (OECD, 2019). This condition is very concerning. Therefore, the Minister of Education formed AKM by adopting PISA.

Research on the development of PISA has been widely carried out in Indonesia. Rawani et al (2019) examined the ability of 15 year old students in the MIA 3 class of SMA 10 Palembang with the method of designing several instruments (RPP, question cards, scoring rubrics, and PISA questions on space and shape content based on the PISA question criteria). Based on the analysis of the results on 33 students, it displayed potential effects on basic mathematical abilities, including the ability of reasoning and argument. It also exhibited that students can develop and solve problems with modeling using their assumptions. 
In addition, the ability to design problem-solving strategies emerged in using various procedures in solving problems that led to the conclusion.

Another research was conducted by Novita et al (2012) examined the problem solving skills of primary school students by performing tasks such as PISA questions (PISA like task). With descriptive analysis based on the test results of one-to-one students and small groups obtained the results of research that most students can use and understand the task well. In addition, based on the results of interviews it is known that they like to perform such tasks because it can improve their abilities and thinking abilities, as well as be able to explore their creativity.

Similar research was also conducted by Wulandari and Jailani (2018) related to the math skills of fifteen-year-old students in Yogyakarta in solving problems such as PISA. With a descriptive quantitative analysis approach obtained math skills of students aged 15 years old in Yogyakarta in solving problems such as PISA better than Indonesian students in PISA 2012, but still fall into the low category.

AKM was planned to be implemented in 2020 but was postponed to 2021 due to the Covid-19 pandemic. Until 2019, all high schools including SMAN Babat and MAN 2 Lamongan are still applying the National Examination according to the direction of the Ministry of Education and Culture. In other words, teachers do not yet have the experience to implement AKM. In addition, in both schools, all teachers have never implemented assessments such as AKM and character surveys.

The fundamental problem found in the field of mathematics in Babat Subdistrict, Lamongan Regency is that the high school teachers do not have the experience to conduct AKM or anything alike. In addition, the teachers have no special assistance in preparing the implementation of AKM.

Previous studies have focused only on measuring students' abilities, not measuring teacher abilities. Therefore, this research was conducted with the aim to know whether there is an improvement in the ability of teachers in understanding and designing AKM-based questions after being given knowledge and trained about it. 
This paper is organized as follows. The background and motivation have been presented in introduction section. Then, the research method section includes the elaboration of data and variables and also steps of analysis. After that, the results of the analysis will be given in results and discussion section. Finally, the conclusion section summarizes this study.

\section{RESEARCH METHOD}

This study is a quantitative study that emphasizes on descriptive analysis. According to Marhamah (2016) descriptive analysis is a statistical technique used to analyze data by describing the collected data as it is without intending to make conclusions that apply to the public or generalization. Quantitative approach is an approach that uses numbers, starting from data collection, interpretation of the data, as well as the appearance of the results (Arikunto, 2013).

The data in this research are primary data obtained directly in the field at the time of the workshop. There were 26 workshop participants as research objects. However, there are some missing data so that a total of only 21 participants will be used in the analysis. There are two variables measured in this study, namely (1) the ability to understand AKM-based questions and (2) the ability to design AKM problems. Data are the result of pre-test and post-test on each of these variables.

The research steps are as follows:

1. Preparation of research instruments that include the design of pre-test and posttest questions

Because this study measures two variables, the pre-test and post-test are also designed based on those variables (the ability to understand AKM-based questions and the ability to design AKM problems). For the first variable, the teachers were given a set of mathematics questions (17 multiple choices and 3 essays), which were AKM-based questions. The pre-test was given before the workshop begin and last for one hour. The same set of questions were given after the workshop with the same duration.

For the second variable, the participants were asked to arrange their own questions (2 questions) three days before the workshop and had to submit it a 
day before the workshop. This task is considered as pre-test for the second variable. For the post-test, the teachers were asked to design 2 AKM-based questions based on their understanding after receiving a lot of knowledge during the workshop. The duration for this test was 60 minutes.

2. Execution of AKM workshop

This workshop was held online via Zoom from 8 am to $3 \mathrm{pm}$. This includes one hour pre-test; one and a half hour lecture about the introduction to AKM-based questions; one hour simulation to design AKM-based questions; and two hours post-tests (post-test 1 and post-test 2).

3. Data collection

The data were collected from the pre-test and post-test results during the workshop.

4. Descriptive analysis of data

The descriptive analysis that used in this study is mean value of the score. Besides, the data were also displayed in pie and bar charts.

5. Drawing conclusions.

The conclusion was drawn based on the descriptive analysis of the data.

\section{RESEARCH RESULTS AND DISCUSSIONS}

After the execution of the introduction to Minimum Competency Assessment (AKM) Workshop, it is necessary to analyze the results of the workshop. In this workshop, teachers who master the field of mathematics will be guided on how to understand and design numeration problems in the field of mathematics in accordance with AKM standards. The proportion of teachers as participants in this workshop is shown in Figure 1 and Figure 2.

Based on Figure 1, the proportion of participants' institutions is almost the same. A total of $54 \%$ participants came from SMAN 1 Babat and the rest (46\%) were from MAN 2 Lamongan. Figure 2 presents the percentage of participants based on the field of study that shows that this workshop was followed by the majority of math teachers with a percentage of $69 \%$ followed by physics, biology and chemistry. 


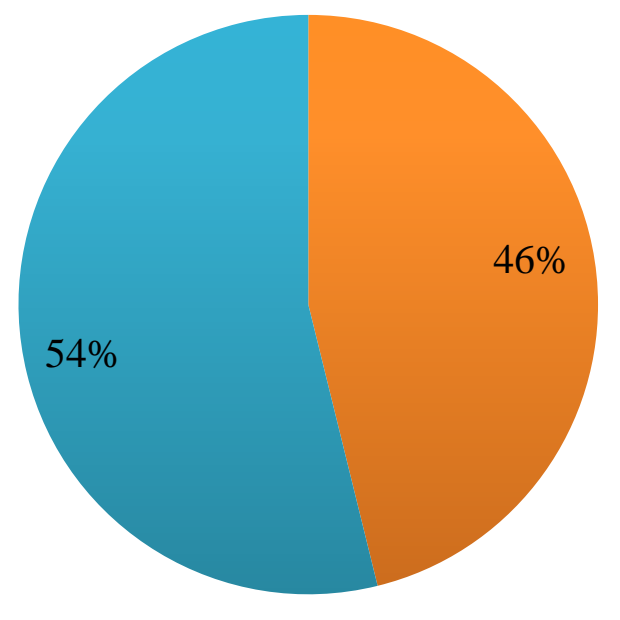

- SMAN 1 Babat $\quad$ MAN 2 Lamongan

Figure 1. Proportion of Workshop Participants by Institution

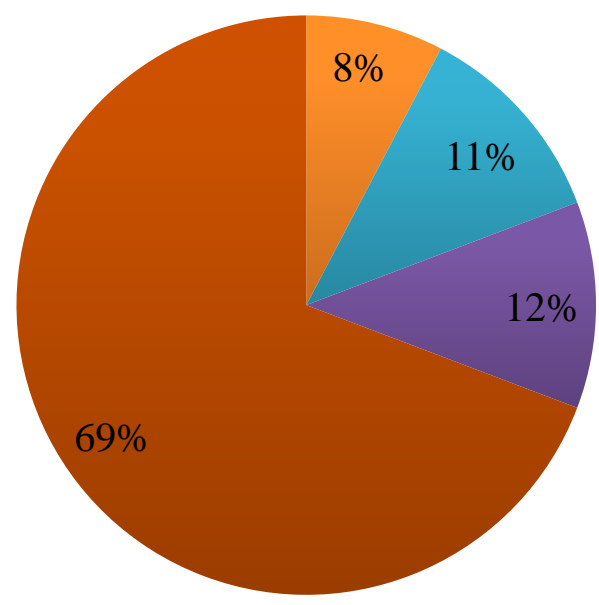

- Chemistry $\quad$ Biology $\quad$ Physics $\quad$ Mathematics

Figure 2. Proportion of Workshop Participants by Field of Study

There are two variables measured in this study to see whether there is an improvement in teachers' abilities. These variables include the ability to understand AKM-based questions and the ability to design AKM-based questions. 


\section{The Ability to Understand AKM-based Questions}

To examine the improvement of the ability of SMAN 1 Babat and MAN 2 Lamongan teachers in understanding AKM-based questions. We conducted pretest and post-test with the results shown in Figure 3.

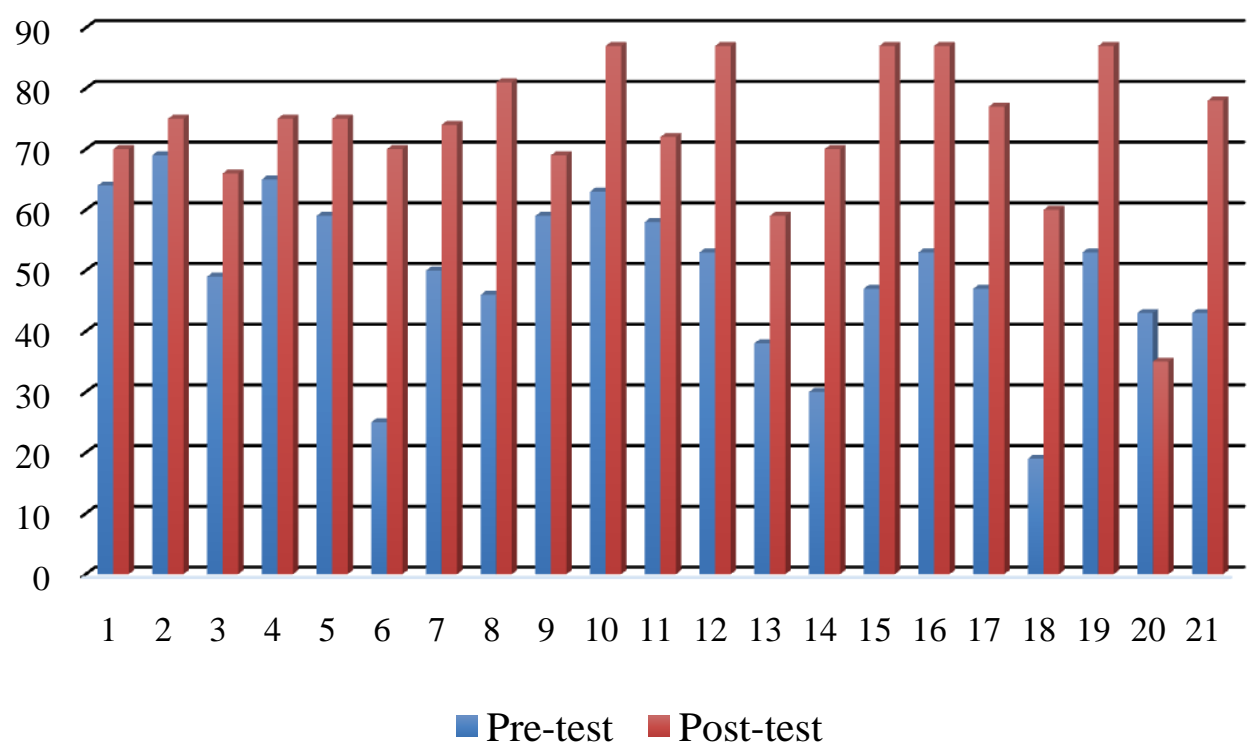

Figure 3. Diagram of Pre-Test and Post-Test Ability to Understand AKM-Based Questions

Based on Figure 3, one can see that there is an increase in the ability to understand about AKM by teachers of SMAN 1 Babat and MAN 2 Lamongan before (pre-test) and after (post-test). Improvement of the comprehension ability is more visible with an average score increase of 24.19 points. This means that there has been an improvement in the ability of teachers in the aspect of understanding about AKM-based questions after attending the workshop.

\section{The Ability to Design AKM-based Questions}

To know the improvement of the ability of SMAN and MAN teachers in Lamongan in designing AKM-based questions, we conducted pre-test and posttest in which the results are shown in Figure 4. 


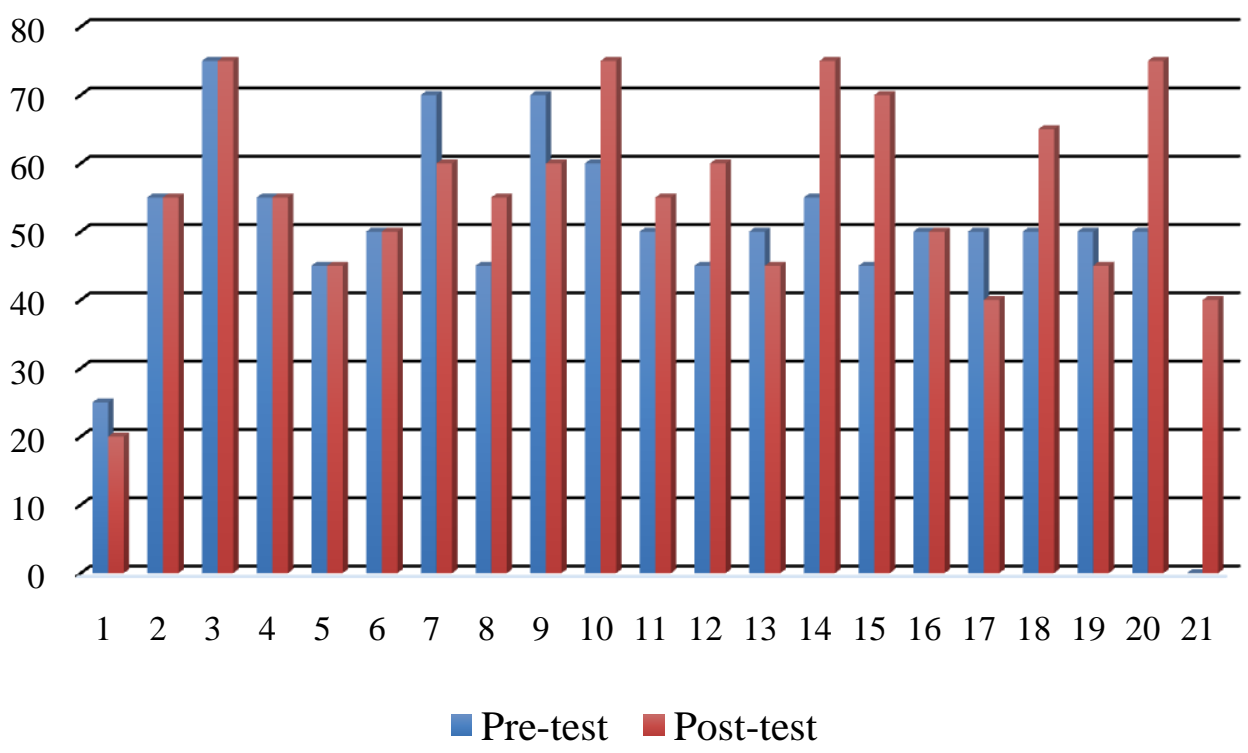

Figure 4 :Diagram of Pre-Test and Post-Test Ability to Design AKM Based-

Question

Based on Figure 4, it is known that there is an increase in the ability to design AKM problems by teachers of SMAN 1 Babat and MAN 2 Lamongan before (pre-test) and after (post-test). However, the average score of increase is only 5.95 points, which is not as high as the ability to understand AKM-based questions. Because these points are still too small compared to the ability to understand the questions, a further assistance is recommended to have a higher competence in designing AKM-based questions.

\section{CONCLUSION}

The Workshop on the Introduction of Minimum Competency Assessment was held to facilitate teachers of SMAN 1 Babat Lamongan and MAN 2 Lamongan in understanding and designing AKM-based quastions. After participating in the workshop, there is an increase in the ability of teachers SMAN 1 Babat and MAN 2 Lamongan in understanding the AKM-based question with an increase in the average post-test value of 24.19 points. However, in the ability to design AKM-based question, there was only an increase of 5.95 points. These improvement values suggest that the teachers need more assistance in designing 
AKM-based questions. Therefore, the recommendation is to conduct a follow-up mentoring regarding the competence to design AKM-based questions.

\section{REFERENCES}

Arikunto, S. (2013). Prosedur penelitian suatu pendekatan praktik. Jakarta: PT. Rineka Cipta.

Bledsoe, T. S., \& Baskin, J. J. (2014). Recognizing student fear: the elephant in the classroom. College Teaching, 62(1), 32-41.

Hadi, A., \& Arwan. (2011). Pro kontra Ujian Nasional (UN) dalam sistem evaluasi pendidikan di Indonesia. Conciencia: Jurnal Pendidikan Islam, 11(2), 79-92.

Kemendikbud. (2019). Tahun 2021, ujian nasional diganti asesmen kompetensi dan survei karakter. Retrieved November 2020, 5, from Kementerian Pendidikan dan Kebudayaan: https://www.kemdikbud.go.id/main/ blog/2019/12/tahun-2021-ujian-nasional-diganti-asesmen-kompetensi-dansurvei-karakter.

Marhamah, S., Maiyastri, \& Asdi Y. (2016). Studi prestasi mahasiswa dengan analisis statistika deskriptif (studi kasus: mahasiswa program studi matematika FMIPA Universitas Andalas tahun 2009-2011). Jurnal Matematika UNAND, 5(4), 36-44.

Ndiung, S., \& Jediut, M. (2020). Pengembangan instrumen tes hasil belajar matematika peserta didik sekolah dasar berorientasi pada berpikir tingkat tinggi. Premiere Educandum: Jurnal Pendidikan Dasar dan Pembelajaran, 10(1), 94-111. http://doi.org/10.25273/pe.v10i1.6274

Novita, R., Zulkardi, \& Hartono, Y. (2012). Exploring primary student's problemsolving ability by doing tasks like PISA's question. Indonesian Mathematical Society Journal on Mathematics Education, 3(2), 133-150. https://doi.org/10.22342/jme.3.2.571.133-150.

OECD. (2019). PISA 2018: latest result. Retrieved November 2020, 5, from PISA, Programme for International Student Assessment: https://www.oecd.org/pisa/

OECD. (2020). What is PISA?. Retrieved November 2020, 5, from PISA, Programme for International Student Assessment: https://www.oecd.org/pisa/

Rawani, D., Putri, R. I. I., \& Hapizah. (2019). PISA-like mathematics problems: using taekwondo context of Asian games. Journal on Mathematics Education, 10(2), 277-288. https://doi.org/10.22342/jme.10.2.5243.277288

Solehah, L. F. N. (2014). Faktor-faktor penyebab kecemasan siswa dalam menghadapi ujian nasional. Perspektif Ilmu Pendidikan, 25(16), 16-32. https://doi.org/10.21009/PIP.251.3

Wulandari, N. F., \& Jailani. (2018). Mathematics skill of fifteen years old students in Yogyakarta in solving problems like PISA. Journal on $\begin{array}{lll}\text { Mathematics } & \text { Education, } & \text { 129-144. }\end{array}$ https://doi.org/10.22342/jme.9.1.4231.129-144 